\author{
Ewa Arleta Kos \\ Uniwersytet Łódzki \\ E-MAIL: ewa.kos@uni.lodz.pl orciD: oooo-ooo3-3009-736o
}

\title{
Funkcjonowanie społeczne dziecka z mutyzmem wybiórczym jako obszar specjalnych potrzeb rozwojowych i edukacyjnych
}

\begin{abstract}
STRESZCZENIE
W niniejszym opracowaniu skoncentrowano się na omówieniu wybranych specjalnych potrzeb edukacyjnych i rozwojowych dziecka z mutyzmem wybiórczym (MW). Mutyzm wybiórczy ma znaczenie dla funkcjonowania jednostki (zwłaszcza w aspekcie społecznym) i stanowi poważne zagrożenie dla zdrowia psychicznego i samopoczucia uczniów.

W pierwszej części opracowania scharakteryzowano specyfikatory diagnostyczne mutyzmu wybiórczego w kontekście ICD-10 i DSM-5. W kolejnej części omówiono specjalne potrzeby edukacyjne i rozwojowe dzieci/uczniów wykazujących objawy mutyzmu wybiórczego. Następnie opisano specyfikę funkcjonowania społecznego dzieci z MW w kontekście ICF-CY (The International Classification of Functioning, Disability and Health for Children and Youth). W ostatnim paragrafie przedstawiono wybrane techniki umożliwiające efektywne włączanie do grupy rówieśniczej i tworzenie warunków sprzyjających uczeniu się dziecku z MW. Scharakteryzowano zakres pomocy psychologiczno-pedagogicznej dla ucznia z MW na terenie przedszkola/szkoły.
\end{abstract}

SŁOWA KLUCzOWE: mutyzm wybiórczy, funkcjonowanie społeczne dzieci z MW, specjalne potrzeby edukacyjne i rozwojowe dzieci z mutyzmem wybiórczym

\section{Wprowadzenie}

Mutyzm wybiórczy jest zaburzeniem, które dotyka coraz więcej dzieci i młodzieży. Uznaje się, iż wskaźnik występowania mutyzmu wybiórczego (MW) w populacji jest relatywnie niski ${ }^{1}$, jednak wpływ tej trudności na funkcjono-

1 Należy podkreślić, iż trudno jednoznacznie określić skalę tego problemu z wielu powodów, które nie będą omówione w niniejszym opracowaniu. Z badań epidemiologicznych z Europy Zachodniej, Stanów Zjednoczonych i Izraela wynika jednak, że MW (jego ekstremalna postać, mutyzm ciężkiego rodzaju) jest zaburzeniem, które obserwuje się w populacji z częstością o,03-0,76\% (Kopp i Gillberg 1997, s. 257-262 cyt. za: Bystrzanowska 2018; Ford, Sladeczeck, Carlson, Kratoch i Will, 1998; Bergman i Piacentini McCracken, 2002; Elizur i Perednik, 2003, s. 1451-1459 cyt. za: Bystrzanowska, 2018) aż do 1,9\% w Finlandii (Kumpulainen i in. 1998, s. 24-29 cyt. za: Bystrzanowska, 2018) 
wanie jednostki jest wszechobecny i stanowi poważne zagrożenie dla zdrowia psychicznego, samopoczucia uczniów (Langdon i Starr, 2019). Celem artykułu jest ukazanie mutyzmu wybiórczego jako źródła specjalnych potrzeb edukacyjnych i rozwojowych, które w toku procesu dydaktyczno-wychowawczego mogą i powinny być zabezpieczone, dzięki stosowaniu przez nauczycieli i terapeutów odpowiednich metod i technik pracy z danym uczniem.

Uczniowie ze specjalnymi potrzebami edukacyjnymi ( $\left.\mathrm{SPE}^{2}\right)$ i specjalnymi potrzebami rozwojowymi (SPR³), niepełnosprawnościami mogą doświadczać bowiem trudności w nauce lub funkcjonowaniu społecznym, które wymagają specjalnej oferty edukacyjnej. Uczniowie z MW na skutek problemów, jakich doświadczają mogą wykazywać obniżoną efektywność w zakresie osiągania sukcesów edukacyjnych, w konsekwencji trudności w nawiązywaniu relacji z rówieśnikami, nauczycielami w instytucji edukacyjnej. Właśnie te problemy podjęte zostaną $\mathrm{w}$ niniejszym opracowaniu.

Edukacja włączająca uczniów ze SPE i SPR stała się obecnie jednym ze światowych trendów. Jednak analizy wyników badań (m.in.: Garrote, Sermier i Dessemontet, 2017; Bystrzanowska, 2018; Furr, Sanchez, Hong i Comer, 2020,) wykazują, że wyłącznie stworzenie możliwości „do bycia” w zespole klasowym dziecku z MW nie wystarcza, aby wspierać jego udział społeczny w życiu klasy, szkoły. Rodzi się zatem pytanie, w jaki sposób można wspomagać uczestnictwo społeczne dzieci z MW. W zakończeniu niniejszego opracowania omówione zostaną wybrane techniki ułatwiające funkcjonowanie dzieciom z MW na terenie szkoły/przedszkola.

\section{Mutyzm selektywny - specyfikatory diagnostyczne}

Mutyzm selektywny jest trudnością, którą rozpoznaje się po tym, iż jednostka nie mówi w określonych sytuacjach społecznych, jednak naturalnie i normalne komunikuje się w innych. Przytaczając zapisy aktualnie obowiązującej Międzynarodowej Klasyfikacji Chorób i Problemów Zdrowotnych (ICD-10) można przyjąć następujące kryteria diagnostyczne MW:

- ekspresja oraz rozumienie języka oceniane wg standaryzowanych testów mieszczą się w granicach dwóch odchyleń standardowych, adekwatnie do wieku dziecka;

2 W opracowaniu wykorzystywany będzie skrót SPE, zawsze będzie oznaczał specjalne potrzeby edukacyjne.

3 W opracowaniu wykorzystywany będzie skrót SPR, zawsze będzie oznaczał specjalne potrzeby rozwojowe. 
- istnieje możliwość weryfikacji, iż niemożność mówienia występuje tylko w określonych sytuacjach, a w innych komunikacja realizowana jest bez utrudnień;

- czas trwania niemożności mówienia przekracza 4 tygodnie (z wyłączeniem pierwszego miesiąca pobytu dziecka w nowym środowisku edukacyjnym);

- nie występuje żadne z całościowych zaburzeń rozwoju;

- braku mówienia nie można wyjaśnić brakiem znajomości języka.

Specyfikatory MW odnaleźć można również w klasyfikacji zaburzeń psychicznych Amerykańskiego Towarzystwa Psychiatrycznego. Zgodnie z kryteriami przyjętymi waktualnej klasyfikacji DSM-5 MW został ujęty jako zaburzenie o charakterze lękowym, tj. wskazano na lęk jako fundamentalną przyczynę tego zaburzenia. Kryteria diagnostyczne MW według DSM-5 są podobne do tych wymienionych powyżej (dodano: niemówienie nie jest efektem braku wiedzy).

Trzeba podkreślić, iż zgodnie z klasyfikacją ICD-10 MW jest jednym z zaburzeń funkcjonowania społecznego, które zazwyczaj ma swój początek w dzieciństwie (najczęściej symptomy MW pojawiają się do 5 roku życia).

Wspólną cechą tej heterogennej grupy zaburzeń są zaburzenia funkcjonowania społecznego rozpoczynające się w okresie rozwoju. W odróżnieniu od całościowych zaburzeń rozwojowych nie występuje tu konstytucjonalnie uwarunkowana niezdolność do interakcji społecznych ani deficyty w zakresie wszystkich sfer funkcjonowania. W wielu przypadkach podstawową rolę w etiologii MW odgrywają poważne nieprawidłowości i niedostatki otoczenia społecznego dziecka (WHO, 2008).

Niektórzy uważają MW za pochodną deficytów rozwoju mowy czy też zaburzenie behawioralne o typie zachowania unikającego (Holka-Pokorska i in. 2018, s. 323).

Jak zostało powiedziane, trudno ocenić skalę problemu w populacji z tego względu, iż MW jest często mylony z innymi trudnościami, zaburzeniami dziecka (m.in. autyzm, zespół stresu pourazowego, fobia społeczna, zaburzenia zachowania o charakterze opozycyjnym, nieśmiałość). MW bywa także błędnie przypisywany dzieciom dwujęzycznym w sytuacjach, w których brak mówienia można wytłumaczyć trudnościami ze zrozumieniem lub nieumiejętnością posługiwania się językiem obcym (https://childmind.org/guide/teachers-guide-to-selective-mutism/).

Podsumowując, MW jest zaburzeniem utrudniającym dziecku funkcjonowanie w środowisku edukacyjnym, zwłaszcza w zakresie oczekiwanej aktyw- 
ności i uczestniczenia w różnych sytuacjach szkolnych, towarzyskich. Utrudnia zatem realizowanie obowiązków wzakresie funkcjonowania emocjonalno-społecznego, w zakresie komunikacji, lecz w konsekwencji także uniemożliwia osiąganie sukcesów w zakresie rozwoju ruchowego, sensorycznego, ale zwłaszcza poznawczego. $Z$ tego względu można uznać, iż dzieci z MW wykazują SPE i SPR, wymagają więc specjalnego, zindywidualizowanego w zakresie tempa i wymagań programu, adekwatnych metod nauczania (Bogdanowicz 1999).

\section{Specjalne potrzeby edukacyjne i rozwojowe uczniów z mutyzmem wybiórczym}

Termin specjalne potrzeby edukacyjne do literatury i praktyki pedagogicznej wprowadzony został przez Mary Warnock już w 1978 roku w zapisach zawartych w dokumencie The Warnock Report. Special Educational Needs (zob. Wiszejko-Wierzbicka, 2012). Obecnie w literaturze przedmiotu funkcjonuje wiele definicji specjalnych potrzeb rozwojowych i edukacyjnych. Odwołując się do definicji, która zaproponowana została przez Członków Zespołu Ekspertów ds. Specjalnych Potrzeb Edukacyjnych, powołanego w 2008 roku przez MEN, można uznać, iż dzieci, młodzież ze SPE i SPR to te, u których stwierdzić można zagrożenie niepełnosprawnością, wszelkiego rodzaju dysfunkcje, dysharmonie, niesprawności, które mogą wywrzeć ujemny wpływ na przebieg ich rozwoju. W odniesieniu do tej definicji można stwierdzić, iż dzieci ze SPE i SPR to te, u których można zdiagnozować pewne zachowania, objawy, które utrudniają, a często uniemożliwiają im efektywne myślenie i działanie w przedszkolu/szkole (lub istnieje uzasadnione podejrzenie, iż stanie się tak w przyszłości) i wypełnianie obowiązków w zakresie funkcjonowania: ruchowego, sensorycznego, poznawczego, emocjonalno-społecznego, w zakresie komunikacji (te dwa ostatnie aspekty są właśnie najistotniejsze z perspektywy niniejszego opracowania).

Termin SPE i SPR jest zazwyczaj wykorzystywany w celu opisania trudności w uczeniu się lub niepełnosprawności, które utrudniają dzieciom naukę i uzyskiwanie efektów porównywalnych z większością dzieci w tym samym wieku. Dzieci ze SPE i SPR zazwyczaj potrzebują dodatkowej lub innego rodzaju pomocy niż udzielana jest innym dzieciom w ich wieku.

Warto nadmienić, iż definicje i kategorie SPE i SPR różnią się w poszczególnych krajach europejskich, łączy je jednak to, iż zazwyczaj odnoszą się do klasyfikacji ICF-CY (klasyfikacja ta zostanie omówiona w kolejnym paragrafie) i podstawowego celu, który został wyrażony w tejże klasyfikacji określonym jako konieczność dążenia do autonomii jednostki w życiu osobistym i społecznym oraz zwiększanie jej uczestnictwa we wszystkich obsza- 
rach życia (Zaremba, 2014). Ponadto wskazuje się, iż SPE wykazuje około $20 \%$ uczniów w wieku szkolnym (Bogdanowicz, 1999; Department for Education (DfE), 2013 - na podstawie: Information on special educational needs (SEN) and related information about special schools in England).

Dzieci z MW z różnych powodów wymagają szczególnej uwagi, wsparcia i dodatkowej pomocy, w ramach wyrównywania ich szans edukacyjnych. Konieczne zwykle okazuje się wsparcie przede wszystkim w zakresie funkcjonowania emocjonalno-społecznego, komunikacji i wsparcia uczestnictwa w strukturze grupy, do której przynależą.

\section{Partycypacja społeczna ucznia z mutyzmem wybiórczym w kontekście opisu skali referencyjnej standaryzacji potrzeb dzieci i młodzieży ze SPE i SPR}

Dokonując opisu funkcjonowania społecznego dzieci z MW wykorzystane zostaną podstawowe pojęcia, a także struktury Międzynarodowej Klasyfikacji Funkcjonowania, Niepełnosprawności i Zdrowia - ICF oraz ICF-CY (The International Classification of Functioning, Disability and Health for Children and Youth). ICF-CY opracowana została przez WHO. Klasyfikacja, która służyć ma zasadniczo opisowi codziennego funkcjonowania jednostki, złożona jest z dwóch części. Każda z nich obejmuje dwa składniki klasyfikacji. Część 1 to Funkcjonowanie i niepełnosprawność. Funkcjonowanie jest tu rozumiane w szerokim aspekcie, obejmuje wszystkie funkcje ciała ludzkiego, aktywności jednostki i wzory uczestniczenia jednostki w różnych sytuacjach życiowych. W ramach tych składników opisać można: funkcje i struktury ciała - chodzi o funkcje ciała ludzkiego, w tym funkcje psychiczne, opisowi podlegają tu procesy fizjologiczne poszczególnych układów, narządy, kończyny. Niepełnosprawność zazwyczaj oznacza pewnego rodzaju zmiany funkcji lub struktur ciała. Można również opisywać funkcjonowanie człowieka w wymiarze społecznym. Dokonując analizy składników określonych jako aktywność i uczestniczenie przyglądamy się działaniom podejmowanym przez jednostkę, rolom, które podejmuje, jakich unika, jak wywiązuje się ze swoich obowiązków, w jakich sytuacjach, okolicznościach podejmuje działanie. MW może przyczyniać się do ograniczenia aktywności, powodować trudności w podejmowaniu działań. Ograniczenia uczestniczenia, które pojawić się mogą w następstwie MW, przejawiać się mogą najczęściej się w postaci problemów wtórnych (np. odrzucenie rówieśnicze, niedostosowanie społeczne, brak umiejętności nawiązywania i utrzymywania relacji społecznych, nabycie wzorców reakcji lękowych, które utrudniają jednostce angażowanie się w różnego typu sytuacje życiowe, wybiórczość w zakresie również innych zachowań). 
Część 2 obejmuje tzw. czynniki kontekstowe. Pierwsza grupa to czynniki środowiskowe. Ich rozpoznanie i opisanie jest niezwykle istotne $\mathrm{z}$ tego względu, iż to właśnie one tworzą fizyczne oraz społeczne środowisko, w którym funkcjonują jednostki. Determinują aktywność człowieka i mogą wywierać pozytywny lub negatywny wpływ na jego funkcjonowanie. Należy pamiętać, iż aktywność jednostki toczy się w kontekście społecznym i właśnie w tym wymiarze uczy się wykonywania określonych czynności, zadań. Czynniki środowiskowe wiążą się oczywiście ze składnikami z obszaru klasyfikacji.

W części 2 ICF-CY opisuje się czynniki osobowe. To charakterystyczne cechy indywidualne jednostki, które niekoniecznie stanowią element zaburzenia poddawanego opisowi. Do tych czynników należą m.in.: płeć, rasa, wiek, cechy osobowościowe, cechy temperamentalne, poziom sprawności fizycznej, sposób spędzania czasu wolnego, styl życia, nawyki, pochodzenie społeczne, wzory oraz strategie radzenia sobie z problemami natury zdrowotnej oraz innymi trudnościami. Czynniki osobowe w przypadku dziecka z MW mają wpływ na jego funkcjonowanie społeczne - mogą mieć wpływ ułatwiający lub utrudniający. Okazuje się, iż MW dotyczy niemalże trzykrotnie częściej dziewczynek niż chłopców (proporcja liczby dziewczynek do liczby chłopców wynosi 2,6 do 1), ponadto rozwija się we wczesnym dzieciństwie, objawy pojawiają się zwykle przed ukończeniem piątego roku życia (Bystrzanowska, 2018).

Warto nadmienić, iż zgodnie z zapisami zawartymi w części 2 ICF-CY obserwacji podlegają także sposoby porozumiewania się za pomocą języka, znaków i symboli, które podejmowane są przez badanego. Uwaga badającego koncentruje się także na aspekcie odbierania i nadawania wiadomości, specyfiki prowadzenia rozmowy, umiejętności włączania się w dyskusje. Porozumiewanie się jest więc niezwykle ważnym aspektem funkcjonowania jednostki, zwłaszcza w obszarze uczestnictwa w życiu społecznym. W diagnozie i usprawnianiu tego obszaru niezbędne są kompetencje z zakresu m.in. psychiatrii, pedagogiki, logopedii, neurologopedii oraz psychologii (Zaremba, 2014, s. 23-25).

Dominującym obszarem SPE i SPR dziecka z MW są więc owe trudności $\mathrm{w}$ zakresie porozumiewania się, a w konsekwencji ograniczenia aktywności i uczestnictwa w życiu grupy, klasy, szkoły, społeczności lokalnej. W następstwie takiego stanu rzeczy dziecko ma problem z pełnym uczestnictwem, korzystaniem z oferty edukacyjnej. Uczeń z MW potrzebuje więc dodatkowego wsparcia, specyficznego oddziaływania dydaktyczno-wychowawczego, mimo iż nie zawsze legitymuje się orzeczeniem lub diagnozą wydaną przez poradnię psychologiczno-pedagogiczną. Największą rolę w procesie terapii odgrywa tu nauczyciel i jego wiedza. 
Mutyzm wybiórczy często nie zostaje zdiagnozowany, a nawet nie rodzą się podejrzenia, że problemy dziecka mogą wynikać z tego zaburzenia, do chwili podjęcia przez nie nauki szkolnej (Bystrzanowska, 2017). Nauczyciele mylą mutyzm np. z nieśmiałością, nadmierną introwersją (m.in. Bystrzanowska, 2017; Mordzak, 2019). Rodzice, opiekunowie mogą natomiast nie uchwycić objawów MW z tego względu, iż komunikacja werbalna, aktywność w zakresie uczestnictwa w życiu rodzinnym nie stanowi problemu.

Wczesne rozpoznanie i podjęcie terapii MW może mieć wpływ na jej przebieg i jej rokowanie. Właśnie z tego względu ważne jest, aby nauczyciele poznali i zrozumieli różnicę między nieśmiałym zachowaniem a objawami MW (Kovac i Furr, 2019).

Terapia ucznia z MW powinna być związana z podjęciem próby zaspokojenia specyficznych potrzeb edukacyjnych i rozwojowych przede wszystkim przez systematyczne zwiększanie uczestnictwa w nauce, kulturze i społeczności szkolnej oraz redukcję wykluczenia z edukacji w ogóle. Niektóre dzieci z MW zagrożone są wykluczeniem $\mathrm{z}$ edukacji o charakterze masowym z powodu towarzyszących trudności. Badania Rutter i in. (1970) dotyczące specyfiki problemów dzieci z MW, wskazują dwa lub więcej rodzajów trudności, a zatem złożone kombinacje SPE i SPR (Rutter i in., 1970). Na przykład problemy dzieci wykazujących objawy MW mogą wiązać ze znacznym ubytkiem słuchu4, nieadekwatnym do oczekiwań zachowaniem (trudności adaptacyjne, zaburzenia zachowania i emocji, zagrożenie niedostosowaniem społecznym), uczeniem się. Niektóre dzieci mogą mieć także niepełnosprawność fizyczną (Dockrell, Ricketts, Palikara, Charman i Lindsay, 2019).

\section{Włączanie do grupy rówieśniczej i tworzenie warunków sprzyjających uczeniu się dziecku z MW - zakres pomocy psychologiczno-pedagogicznej dla ucznia z mutyzmem wybiórczym na terenie przedszkola/szkoły}

Minister Edukacji Narodowej w rozporządzeniu z dnia 30 kwietnia $2013 \mathrm{r}$. w sprawie zasad udzielania i organizacji pomocy psychologiczno-pedagogicznej w publicznych przedszkolach, szkołach i placówkach (Dz.U. z 2013 r.,

4 Przyczyn MW można się bowiem doszukiwać się również w deficytach funkcjonowania analizatora słuchowego. Zgodnie z koncepcją Y. Bar-Haima oraz Y. Henkina dzieci z MW mają trudności w równoczesnym radzeniu sobie z przychodzącymi dźwiękami i głośną samowokalizacją. U wielu dzieci z MW można rozpoznać deficyty w zakresie funkcjonowania systemów MOCB (Medial Olivocochlear Bundle - refleks środkowej wiązki oliwkowo-ślimakowej) i MEAR (Middle-Ear Acoustic Reflex - refleks akustyczny ucha środkowego), eferentnych systemów zaanagażowanych w monitorowanie i regulację procesów wokalizacji (Bar-Haim, Henkin, 2004; Holka-Pokorska, 2018). 
poz. 532), następnie rozporządzeniu zmieniającym $\mathrm{z}$ dnia 28 sierpnia $2017 \mathrm{r}$. (Dz.U. 2017 poz. 1643) stwierdza, iż pomoc o charakterze psychologiczno-pedagogicznym, która jest oferowana uczniowi w przedszkolu, szkole i placówce polegająca na rozpoznaniu i zaspokajaniu indywidualnych potrzeb rozwojowych i edukacyjnych wynikać powinna m.in. w szczególności:

- z niepełnosprawności;

- $\mathrm{z}$ niedostosowania społecznego;

- z zaburzeń zachowania lub emocji;

- ze specyficznych trudności w uczeniu się;

- z deficytów kompetencji i zaburzeń sprawności językowych;

- z sytuacji kryzysowych lub traumatycznych;

- z niepowodzeń edukacyjnych.

Uczeń z MW wymaga więc pomocy psychologiczno-pedagogicznej oferowanej w przedszkolu/szkole. Zgodnie z wyżej przywołanymi zapisami rozporządzenia to nauczyciele, wychowawcy grup przedszkolnych oraz specjaliści zatrudnieni w przedszkolu, szkole powinni rozpoznawać indywidualne możliwości, potrzeby rozwojowe i edukacyjne uczniów, zwracając uwagę na ich zainteresowania i uzdolnienia.

Jest to szczególnie istotne $\mathrm{w}$ kontekście pracy z uczniem z MW w palcówce, w sytuacji, gdy nauczyciel, wychowawca powinien zaplanować i wdrożyć określone procedury zaradcze. Zwłaszcza gdy skala trudności i problemów dziecka/ucznia nie jest jeszcze rozległa. W sytuacji dostrzeżenia problemów ucznia w zakresie komunikacji werbalnej, podejrzenia MW dziecku należy udzielić pomocy psychologiczno-pedagogicznej niezwłocznie w trakcie bieżącej pracy.

Zgodnie $\mathrm{z}$ zapisami zawartymi $\mathrm{w}$ ICF-CY proces udzielania pomocy psychologiczno-pedagogicznej składa się z trzech faz. Faza 1, to wstępna identyfikacja problemu. Należy określić objawy i ustalić ich odziaływanie na funkcjonowanie szkolne/przedszkolne, a także ogólne samopoczucie dziecka. Okres ten wymaga zaangażowania i samodzielności w myśleniu i działaniu nauczyciela.

Faza 2 to diagnoza. Istotne jest tu opisanie trudności i zidentyfikowanie tych obszarów funkcjonowania dziecka, na które diagnozowany problem ma wpływ. Ważne jest również zidentyfikowanie przyczyn trudności. Przyczyny MW są szeroko opisywane w literaturze (m.in. Bystrzanowska, 2017; Holka-Pokorska, 2018). Mówiąc najogólniej, do potencjalnych przyczyn MW można zaliczyć te, które tkwią w środowisku rodzinnym dziecka (m.in. postawa 
nadmiernej kontroli, nadmiernej opiekuńczości ze strony opiekunów, nabyte wzorce reakcji lękowych, niska jakość i ilość podejmowanych interakcji werbalnych w domu rodzinnym, wielojęzyczność w rodzinie - pochodzenie migracyjne) oraz czynniki tkwiące w środowisku pozarodzinnym (m.in. wzór unikania konfrontacji $\mathrm{w}$ środowisku przedszkolnym/szkolnym, niesprzyjające postawy nauczycieli, opiekunów, trudności w relacjach z rówieśnikami). Wskazuje się także na czynniki audiologiczno-neurologiczne i hormonalne. W przypadku MW nauczyciel może oprzeć się na własnych obserwacjach, następnie na diagnozie wydanej przez specjalistów zatrudnionych w PPP, w placówce, lekarzy - zawłaszcza lekarza psychiatrę.

W fazie 3, która polega na konceptualizacji programu pomocy i wsparcia, należy określić cel programu, opisać planowane zadania i sposób realizacji zadań. Warto także zaplanować strategię ewaluacyjną (Zaremba, 2014, s. 32).

Po etapie rzetelnej oceny diagnostycznej powinna rozpocząć się indywidualna praca ucznia z nauczycielem we współpracy z rodzicami, opiekunami i innymi specjalistami, którzy mają doświadczenie w leczeniu MW. Oddziaływanie terapeutyczne polega przede wszystkim na wyspecjalizowanej terapii behawioralnej za pomocą technik, które przyspieszają pojawienie się komunikatów werbalnych, a następnie utrwalają je dzięki stosowaniu przez terapeutę pochwał i zachęt. Inne opcje terapii są często niedostępne dla najmłodszych dzieci z MW, niski wskaźnik występowania zaburzenia w populacji i rodzaj problematycznych zachowań towarzyszących wykazywanych przez dziecko (Cotter, Todd i Brestan-Knight, 2018).

Z perspektywy skutecznego zaspokajania specjalnych potrzeb edukacyjnych i rozwojowych dziecka $\mathrm{z}$ MW w zakresie włączania w uczestnictwo grupy/klasy możliwości oddziaływania terapeutycznego są ograniczone oraz kontrowersyjne. Stwierdzono, że oddziaływania związane z nauczaniem strategii interakcji, pobudzaniem aktywności werbalnej w toku organizowania zajęć grupowych, grup wsparcia dla uczniów z SPE i SPR poprawiają udział społeczny uczniów (Garrote, Sermier i Dessemontet, 2017). W przypadku uczniów z MW, niestety, zajęcia w grupie odnoszą przeciwny skutek. Z racji tego, że uczniowie ci mają trudność w zakresie pełnego uczestnictwa w grupie rówieśniczej, a działania, które mogłyby ten problem niwelować, z racji swojej specyfiki właśnie w formie grupowej są proponowane, możliwość zapewnienia skutecznej pomocy dla uczniów z MW jest ograniczona.

Pomoc dziecku z MW powinna być przede wszystkim skoncentrowana na wspieraniu go w codziennym stawianiu czoła trudnym sytuacjom, uświadomieniu dziecku, że nie powinno ich unikać. Takie działania sprawiają, iż z czasem lęk dziecka zanika. Podstawową zasadą jest jednak całkowite zanie- 
chanie wywierania nacisku na aktywność werbalną, nakłaniania, zmuszania do mówienia.

Zamysłem niniejszego opracowania nie jest omówienie typów i przebiegu terapii dziecka z MW, przywołane zostały jedynie niektóre ze strategii, które mogą być pomocne w kształtowaniu przyjaznego środowiska edukacyjnego i włączaniu dziecka waktywność grupy rówieśniczej. Jak zostało wspomniane, błędem jest oczekiwanie aktywności werbalnej w sytuacji, gdy dziecko nie jest na nią gotowe. Jeśli dziecko komunikuje się niewerbalnie, potrafi używać gestów, mimiki i sygnałów ręki (np. wskazywanie, kiwanie głową, kciuk w górę lub w dół) należy to wykorzystywać. Aktywność niewerbalna pozwala bowiem dzieciom uczestniczyć w zajęciach edukacyjnych. Z czasem jest szansa, iż przy wsparciu nauczyciela pojawią się komunikaty werbalne. Akceptacja komunikacji niewerbalnej często pozwala na zaspokojenie potrzeb społecznych dziecka i pokazanie, że jego udział w życiu grupy jest ceniony.

Dzieci z MW mają tendencje do wybierania wśród dzieci jednego, z którym pozostają w kontakcie werbalnym. Akceptacja i wspieranie takiego stanu rzeczy pozwala zmniejszyć poziom niepokoju dziecka i w konsekwencji zwiększyć szansę, że będzie mówić do reszty członków grupy, klasy, społeczności szkolnej. Organizowanie pracy w małych grupach także sprzyja uaktywnianiu się dzieci z MW, w mniejszej grupie czują się pewniej i mogą częściej wypowiadać się.

Istotne jest rozpoznanie i bazowanie w toku pracy dydaktyczno-wychowawczej na mocnych stronach i zainteresowaniach dziecka. Dzieci z MW czują się bardziej zaangażowane i pewne siebie, kiedy mogą odkrywać rzeczy, którymi są naprawdę zainteresowane, wykorzystują swoje talenty. Można to wykorzystać, aby dziecko mogło czuć się dobrze w grupie.

Dzieci z MW czerpią ogromne korzyści emocjonalne z możliwości przyjścia do klasy z rodzicami i pobycia w danym miejscu zanim ktokolwiek się tam pojawi. Pozwala to dziecku ćwiczyć mówienie w określonych okolicznościach bez presji ze strony nauczyciela lub rówieśników. Optymalną sytuacją jest, gdy po tym czasie spędzonym wyłącznie z rodzicami, pozwoli się na czas, w którym dołącza sam nauczyciel, a dopiero później reszta grupy (Bystrzanowska, 2017 i in.). Organizowanie pracy chociażby w ten sposób jest formą zindywidualizowanego wsparcia mającego na celu zaspokojenie specyficznych potrzeb edukacyjnych i rozwojowych dziecka z MW.

\section{Zakończenie}

Celem niniejszej pracy było ukazanie mutyzmu wybiórczego jako potencjalnego źródła specjalnych potrzeb edukacyjnych i rozwojowych. Dzieci z MW 
często wykazują specjalne potrzeby edukacyjne i rozwojowe, o czym zapomina się w codziennej praktyce edukacyjnej. Zdarza się, iż MW powiązany jest z niepełnosprawnościami (np. powodowanymi zaburzeniami w zakresie funkcjonowania analizatora słuchowego). Dzieci mogą mieć trudności w nauce, a na pewno wykazywać obniżoną efektywność w zakresie osiągania sukcesów edukacyjnych w konsekwencji trudności w nawiązywaniu relacji z rówieśnikami, nauczycielami w instytucji edukacyjnej. Zazwyczaj MW w bardzo dużym stopniu wpływa na funkcjonowanie społeczne ucznia, dla którego wsparciem okazuje się stworzenie indywidulanej, specjalnej oferty edukacyjnej. Z racji wciąż niewielkiej liczby opracowań poświęconych MW warto wciąż doskonalić techniki pracy zdziećmi z MW, rozpoznawać je empirycznie i upowszechniać je.

\section{BIBLIOGRAFIA}

Bar-Haim, Y., Henkin, Y., Ari-Even-Roth, D., Tetin-Schneider, S., Hildesheimer, M. i Muchnik, C. (2004). Reduced auditory efferent activity in childhood selective mutism. Biological Psychiatry, nr 55(11), 1061-1068.

Bogdanowicz, M. (1999). Model kompleksowej pomocy osobom z dysleksją rozwojową - ocena stanu aktualnego i propozycje zmian w świetle reformy systemu edukacji. Psychologia Wychowawcza, $\mathrm{nr}$ 3, 217-227.

Bystrzanowska M. (2017), Mutyzm wybiórczy. Poradnik dla rodziców, nauczycieli i specjalistów. Kraków: Oficyna Wydawnicza Impuls.

Cotter, A., Todd, M. i Brestan-Knight, E. (2018). Parent-Child Interaction Therapy for Children with Selective Mutism (PCIT-SM). W: L. Niec (red.), Handbook of Parent-Child Interaction Therapy. Springer, Cham.

Dockrell, J., Ricketts, J., Palikara, O., Charman, T. i Lindsay, G. (2019). What Drives Educational Support for Children With Developmental Language Disorder or Autism Spectrum Disorder: Needs, or Diagnostic Category? Frontiers in Education, nr 4(29).

Garrote, A., Sermier, R. i Dessemontet, R. (2017). Facilitating the social participation of pupils with special educational needs in mainstream schools: A review of school-based interventions. Educational Research Review, nr 20, 12-23.

Fernandez, K. i Sugay, C. (2016). Psychodynamic play therapy: A case of selective mutism. International Journal of Play Therapy, nr 25(4), 203-209.

Langdon, H., Starr, M. (2019). Collaboration between a speech and language patholoigst. Listy klinické logopedie, t. 3, $\mathrm{nr}$ 1, 78-82.

Holka-Pokorska, J., Piróg-Balcerzak, A. i Jarema, M. (2018). The controversy around the diagnosis of selective mutism - a critical analysis of three cases in the light of modern research and diagnostic criteria. Psychiatria Polska, nr 52(2), 323-343.

Kovac, L. i Furr, J. (2019) What Teachers Should Know About Selective Mutism in Early Childhood. Early Childhood Education, nr 47, 107-114.

Furr, J., Sanchez, A., Hong, N. i Comer, J. (2020). Exposure therapy for childchood selective mutism: principles, practices, and procedures. W: T.S. Peris, E.A. Storch i J.F. McGuire (red.), Exposure Therapy for Children with Anxiety and OCD. Los Angeles, CA: Academic Press.

Mordzak, M. (2019). Mutyzm wybiórczy w codzienności. Wydawnictwo E-bookowo.

Zaremba, L. (2014). Specjalne potrzeby rozwojowe i edukacyjne dzieci i młodzieży. Identyfikowanie SPR i SPE oraz sposoby ich zaspokajania. Warszawa: ORE. 
Rozporządzenie Ministra Edukacji Narodowej z dnia 30 kwietnia 2013 r. w sprawie zasad udzielania i organizacji pomocy psychologiczno-pedagogicznej w publicznych przedszkolach, szkołach i placówkach (Dz.U. z 2013 r., poz. 532)

Rozporządzenie Ministra Edukacji Narodowej z dnia 28 sierpnia 2017 r. zmieniające rozporządzenie w sprawie zasad udzielania i organizacji pomocy psychologiczno-pedagogicznej w publicznych przedszkolach, szkołach i placówkach (Dz.U. 2017 poz. 1643).

https://open.library.ubc.ca/cIRcle/collections/ubctheses/24/items/1.0384848 (data dostępu 27.04.2020).

https://childmind.org/guide/teachers-guide-to-selective-mutism/ (data dostępu 27.04.2020).

\section{SUMMARY}

\section{Social Functioning of a Child with Selective Mutism as an Area of Special Developmental and Educational Needs}

The aim of this study is to focus on the special educational and developmental needs of a child with selective mutism. Selective mutism is important for human social functioning and is a serious threat to the mental health and well-being of students. Unfortunately, not many teachers are aware of this fact.

The first part of the study discusses the diagnostic specifiers of selective mutism in the context of ICD-10 and DSM-5. The next section discusses the special educational and development needs of children/ students who experience symptoms of selective mutism. Then the author presents a description of the social functioning of children with selective mutism in the context of ICF-CY (The International Classification of Functioning, Disability and Health for Children and Youth). In the last paragraph of this study, the author discusses selected techniques that enable the effective inclusion of a child into a peer group and create an environment that favors the learning of a child with selective mutism. Next the author describes the range of psychological and pedagogical assistance for students with selective mutism in the kindergarten / school.

KEY WORDS: selective mutism, social functioning of children with selective mutism, special educational needs of children with selective mutism 